\title{
A Comparative Study of the Challenges and Opportunities of Higher Education in the Corona Pandemic in Iran and around the World
}

\begin{abstract}
Introduction: The sudden outbreak of Covid 19 has affected the world's higher education system and has led to changes in conventional teaching methods at most universities. The purpose of this study is a comparative study of challenges and opportunities of higher education during the Corona pandemic in Iran and the world.

Methods: The present study is a review study. Data using a systematic review of information resources in the databases ProQuest, Science direct, Scopus, PubMed, Google Scholar, in the period 2019 and 2020 based on the keywords Corona, Medical education, higher education, Challenge, opportunity was done. Finally, out of 44 collected articles, 31 articles were studied. Resource analysis was performed in the form of documentary content analysis.

Results: Based on the findings of the present study, 28 challenges and 24 opportunities each were found in 6 areas of resource analysis that are considered as challenges and opportunities of higher education during the Corona pandemic in Iran and the world. These challenges and opportunities are two different aspects of the impact of Corona on higher education.

Conclusion: According to the research findings, it is recommended that university officials and administrators develop appropriate measures and decisions, laws and regulations required in critical situations such as Corona. Also provide the necessary guidance to change the approach of traditional education to elearning and combination education in order to promote higher education.
\end{abstract}

Keywords: Challenges, Opportunities, Higher Education, Comparative Study, Iran, World.

\section{Article Info}

Authors:

Taghizadeh $\mathrm{S}^{1} \oplus$

Haji $\mathrm{J}^{2}$ ๑

Mohammadimehr $\mathrm{M}^{3 *} \odot$

Received: 2020/6/22

Accepted: 2020/8/15

E-Published: 2020/9/13

\footnotetext{
Affiliations

1- PhD in Higher Education Management, Allameh Tabatabai University, Tehran, Iran.

2- Master of Educational Management and Education Teacher, Mahabad, Iran.

3- PhD in Curriculum Studies, Associated Professor, Department of Laboratory Sciences, Faculty of Paramedical Sciences, Aja University of Medical Sciences. Tehran, Iran.

Corresponding Author: mojganmehr20@yahoo.com
}

\section{Citation Subjects:}

Activities, Educational, Educational Activities, Literacy Programs, Training Programs, Comparison of outcomes, Globe 
فصلنامه يرستار و پزشك در رزم / تابستان 99 / سال هشتم

\section{مطالعه تطبيقى جالشها و فرصتهاى آموزش عالى در دوران پاندمى كرونا در ايران

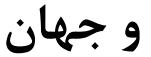

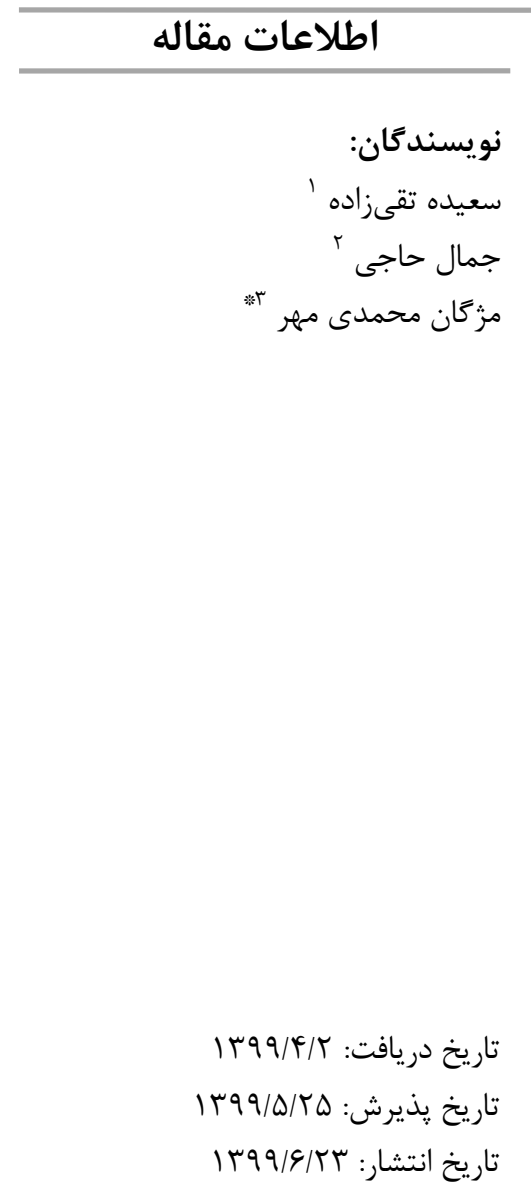

جكيده

مقدمه: شيوع ناكمانى كوويد 19 نظام آموزش عالى جهان را تحت تاثير خود قرار داده

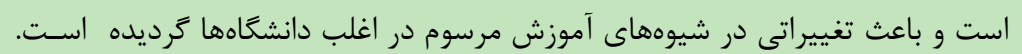

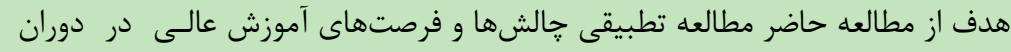

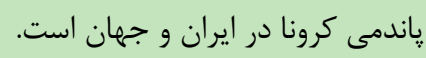

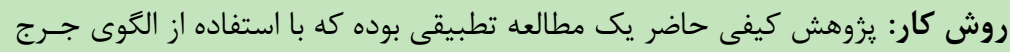

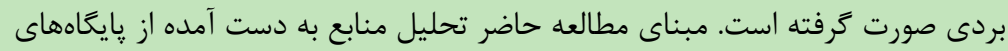
ProQuest, Science direct, Scopus, PubMed, Google Scholar اطلاعات باتى

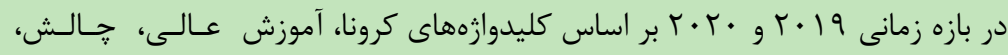

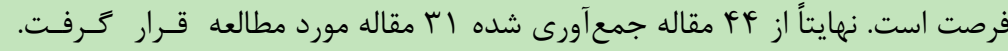

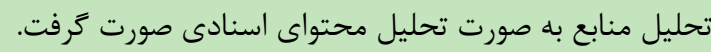

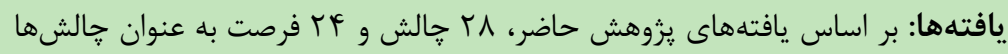

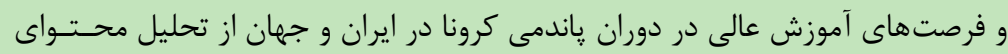

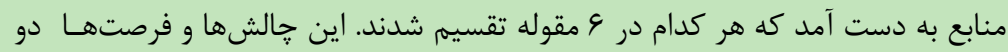

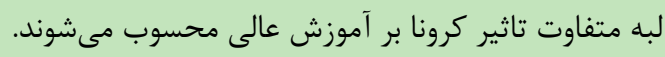

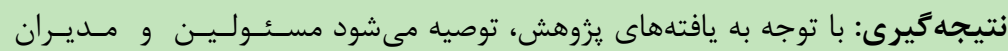

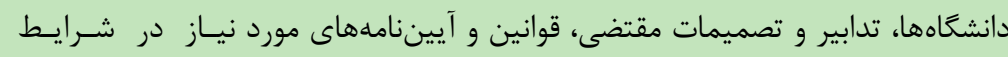

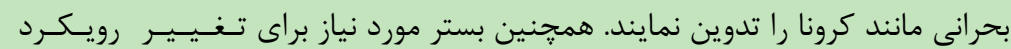

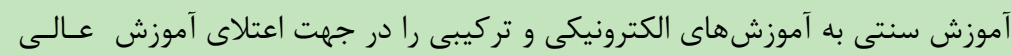
فر اهم نمايند.

وازكًان كليدى: حالشها، فرصتها، آموزش عالى، مطالعه تطبيقى، ايران، جهان.

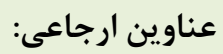

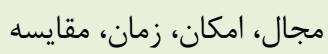

وابستكى سازمانى نويسندكان

1 - دكتراى مديريت آموزش عالى دانشكاه علامه طباطبائى، تهران، ايران.

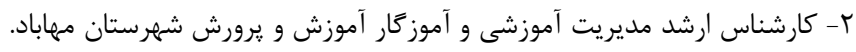

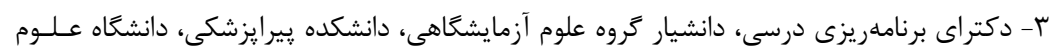
يزشكى ارتش جمهورى اسلامى ايران، تهران، ايران.

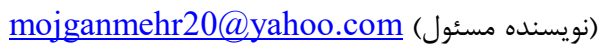




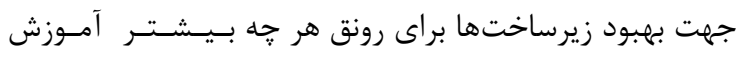

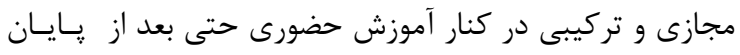

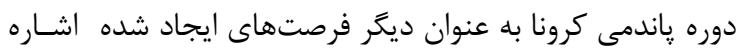

از آنجايى كه شناخت هر جه بيشتر جالش

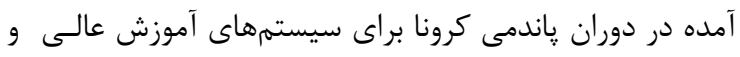

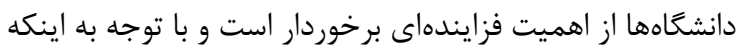

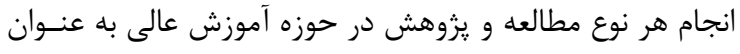

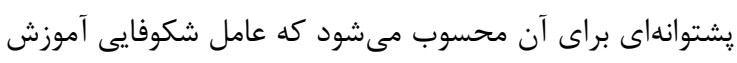

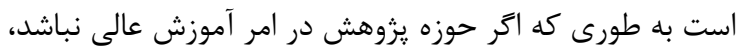

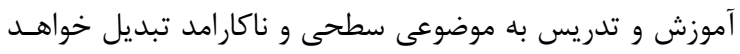

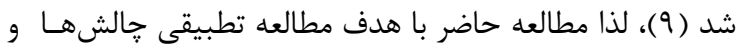

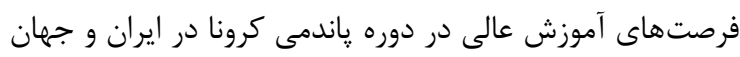

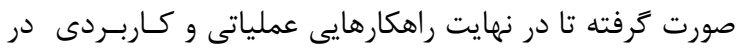

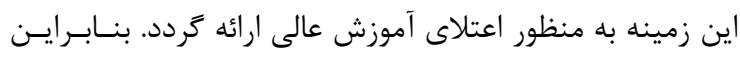

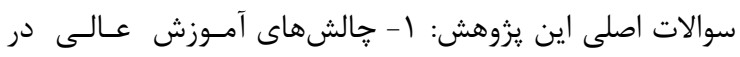

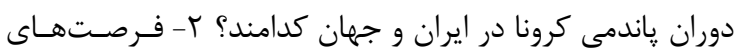

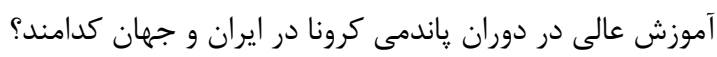

روش كار

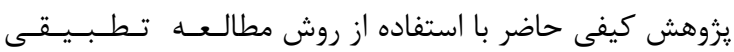

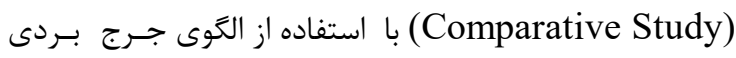

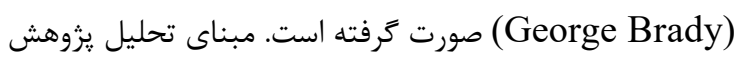

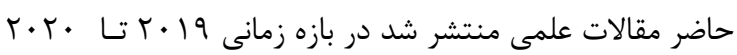

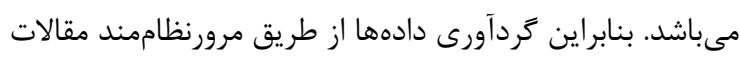

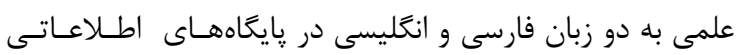
SScience direct ،Scopus ،PubMed ،Google Scholar ProQuest منابع در يايگاههاى اطلاعاتى با استفاده از كليدوازمهاى كـرونـا،

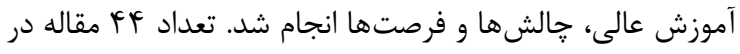

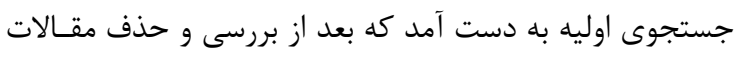

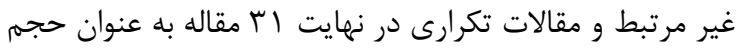

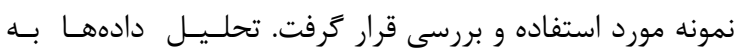

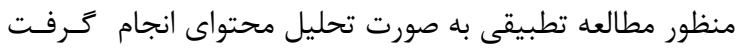

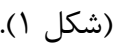

يافتهها

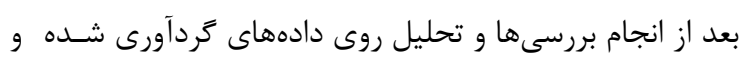

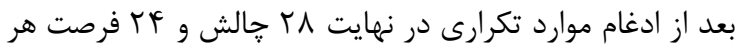

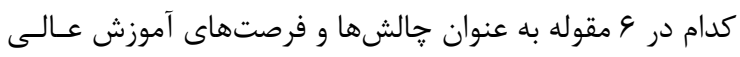

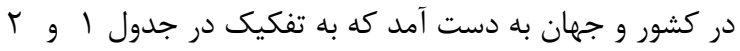

ارائه شده است.
مقدمه

بيمارى كوويد9 ا ناشى از كرونا ويروس اولين بار در د دسـامسبـر

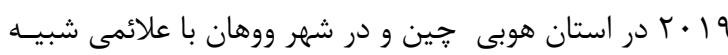

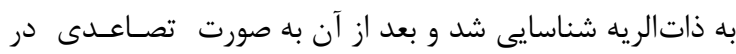

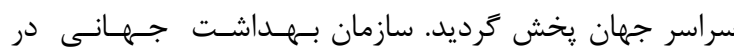

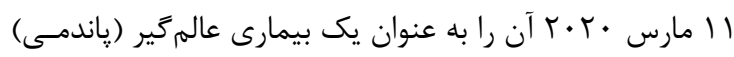

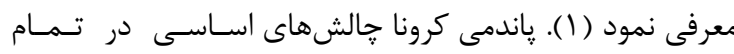

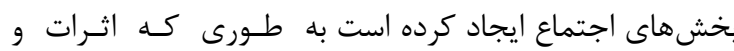

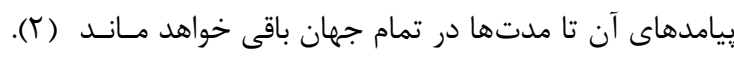

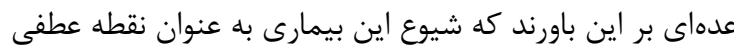

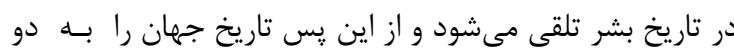

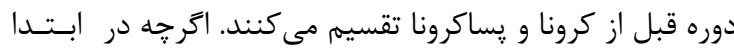

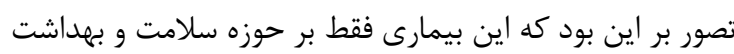

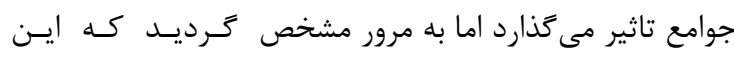

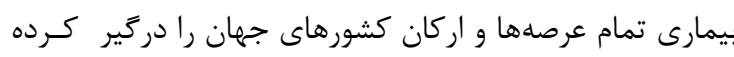

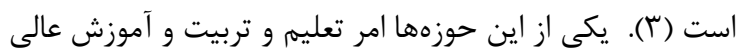

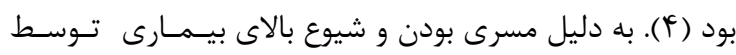

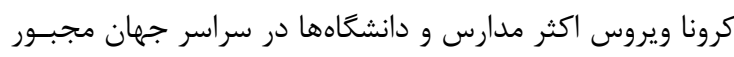

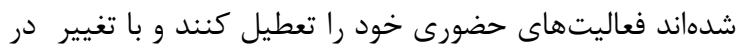

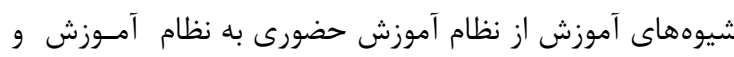

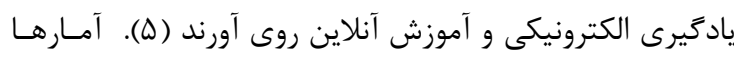

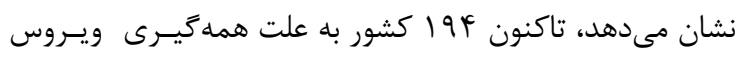

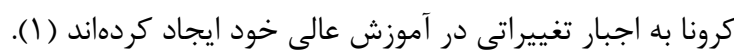

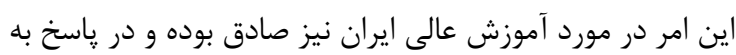

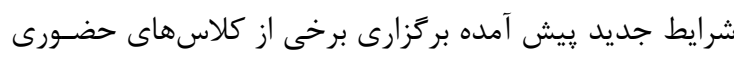

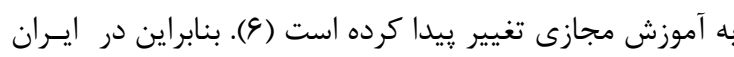

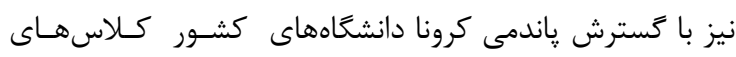
آموزشهاى خود را به بستر آموزش مجازى و تركيبى و واندئ آموزش

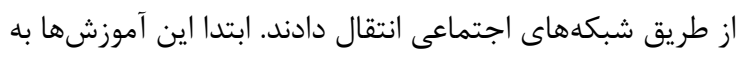

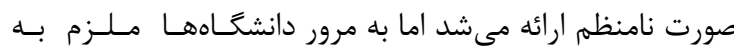

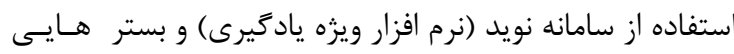

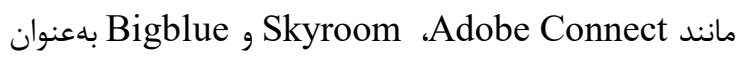
يك سامانه متمركز آموزشى شدند و آموزش در اين دانشكاههـا

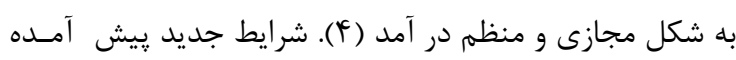

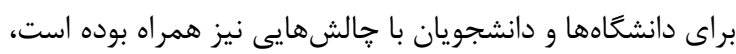

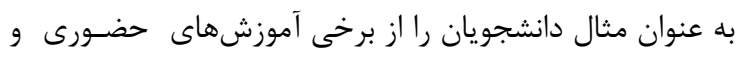

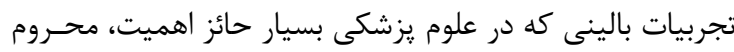

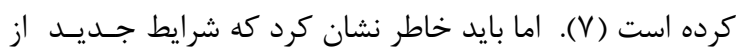

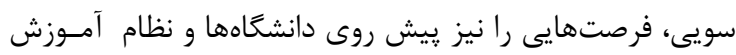

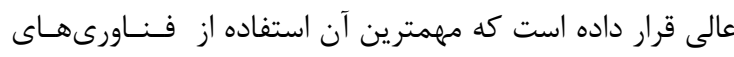

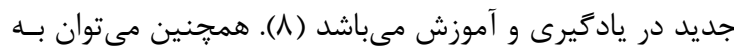

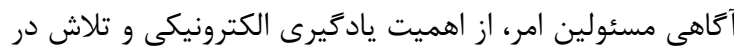




\section{شكل ا: مسير و روش انجام و تحليل يزوهش}
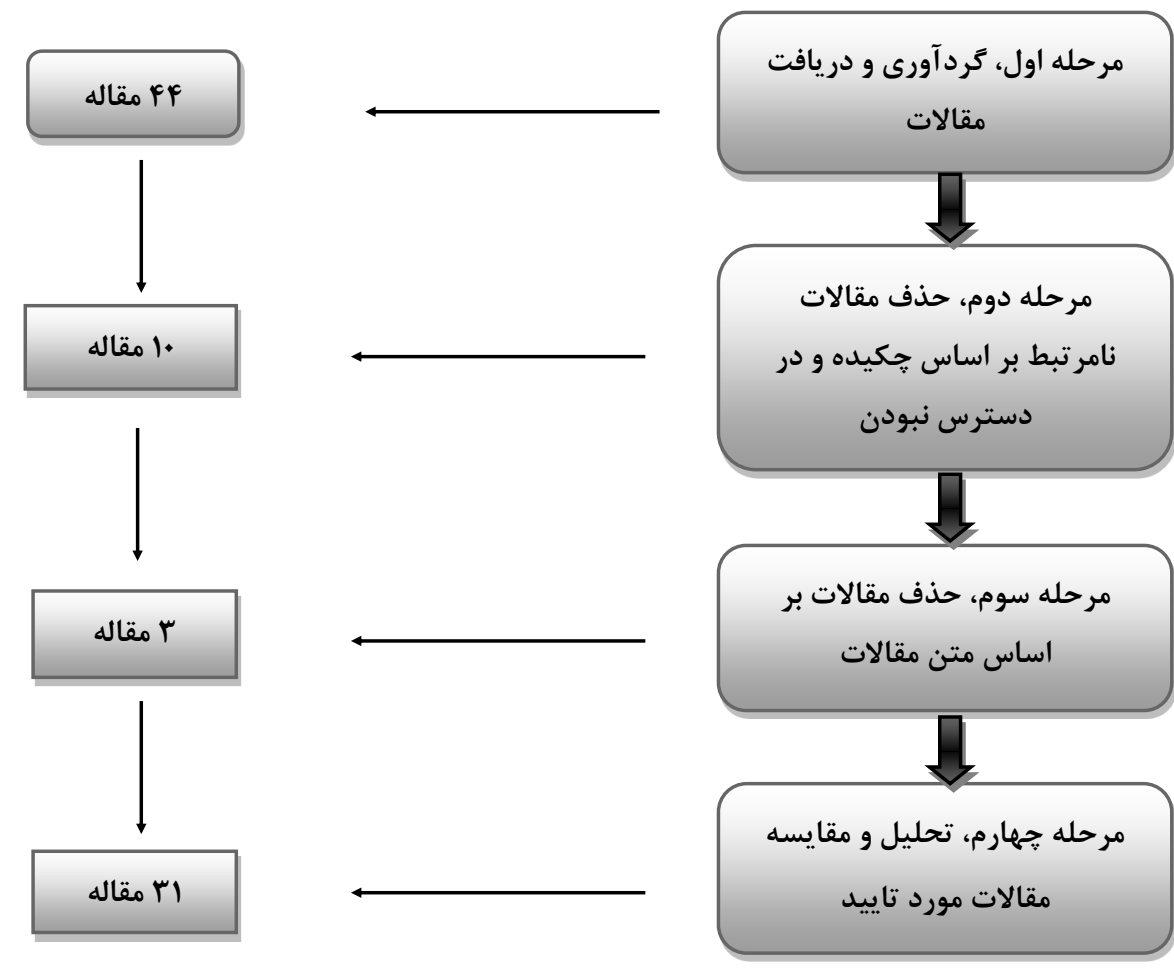

جدول ا: جالشهاى آموزش عالى در دوران پاندمى كرونا ويروس 19 ب در ايران و جهان

\begin{tabular}{|c|c|c|c|}
\hline 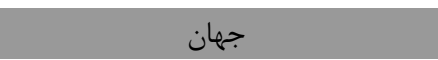 & 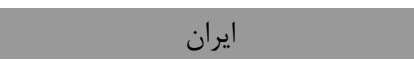 & 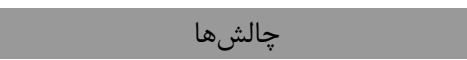 & 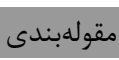 \\
\hline $\begin{array}{l}\text { UNESCO (2020); Lau, Yang } \\
\text { \&Dasgupta }(2020) ;(11.1 \text { r) }\end{array}$ & 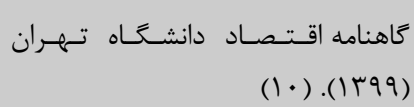 & كاهش جذب دانشجويان & \multirow{7}{*}{ 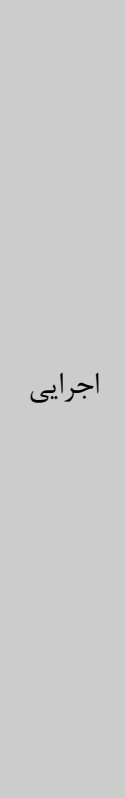 } \\
\hline $\begin{array}{l}\text { Vershitskaya \& etal (2019) } \\
\text { (YI) }\end{array}$ & 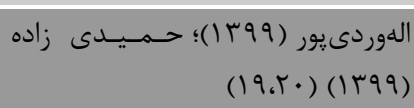 & ايجاد هرج و مرج در دانشكاهها & \\
\hline $\begin{array}{l}\text { Vershitskaya \& etal (2019) } \\
\text { (YI) }\end{array}$ & 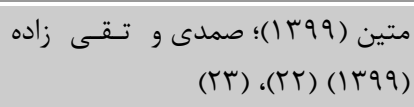 & آزمون و خطا رفتن مسئولين به دليل ابهام & \\
\hline $\begin{array}{l}\operatorname{UNESCO}(2020) ; \operatorname{THE}(2020) \\
(11.1 \wedge)\end{array}$ & 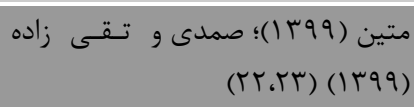 & 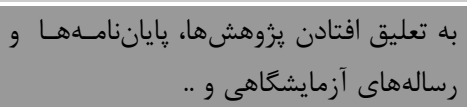 & \\
\hline Sessoms $(2020)(\ulcorner\wedge)$ & 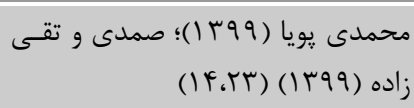 & طولانى شدن مدت زمان تحصيل & \\
\hline Sessoms $(2020)(\ulcorner\wedge)$ & 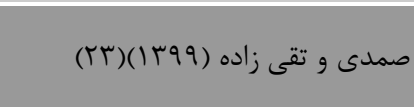 & 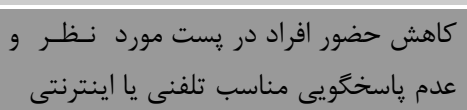 & \\
\hline $\begin{array}{l}\text { Lau, Yang \& Dasgupta } \\
(2020) ;(I r)\end{array}$ & $\begin{array}{l}\text { Shafiei Sarvestani, } \\
\text { Mohammadi, Afshin, } \\
(\text { (2019)(Ir) }\end{array}$ & جالش حضور و غياب & \\
\hline $\begin{array}{l}\text { Department for Education } \\
(2020)(\text { ( })\end{array}$ & 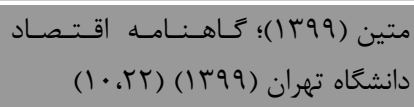 & كاهش حقوق اساتيد و كارمندان & \\
\hline 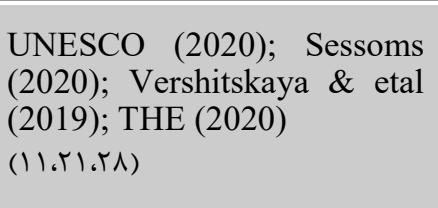 & 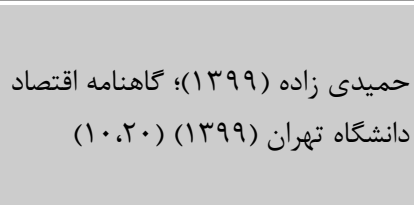 & 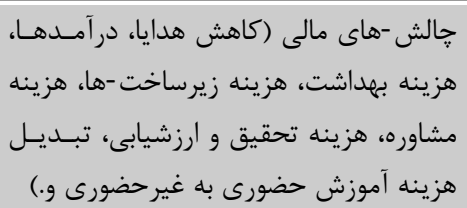 & 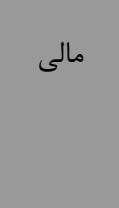 \\
\hline
\end{tabular}




\begin{tabular}{|c|c|c|c|}
\hline جهان & 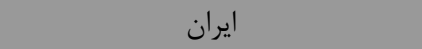 & جالش ها & 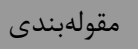 \\
\hline Sessoms $(2020)(r \wedge)$ & 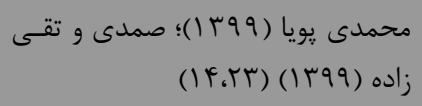 & عدم امكان اسكان & \multirow{4}{*}{ زيرساخت } \\
\hline $\begin{array}{l}\text { Lau, Yang \& Dasgupta (2020); } \\
\text { UNESCO (2020)(11.1Y) }\end{array}$ & متين (Y)(ו) (Y) & 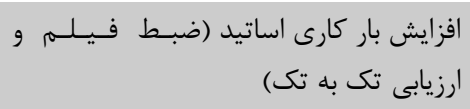 & \\
\hline $\begin{array}{l}\text { Lau, Yang \& Dasgupta (2020); } \\
\text { UNESCO }(2020)(11.1 \text { r) }\end{array}$ & متين (IT) (IT) (Y) & خ واموش كردن دوربين و ميكروفن (اساتيـد & \\
\hline $\begin{array}{l}\text { UNESCO } \quad(2020) ; \quad \text { THE } \\
(2020) ; \quad \text { Mohammadimehr } \\
(2020)(\mid 1.10 .1 \wedge)\end{array}$ & 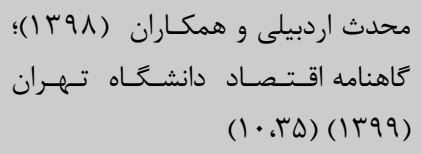 & و سخت توجه به بسترها، زيرساخت ها، فناورى & \\
\hline \multirow[t]{4}{*}{$\begin{array}{l}\text { UNESCO (2020); Ngumbi } \\
(2020) ;(\mid \vee)((1) \mathrm{THE}(2020) \\
(\mid \wedge)\end{array}$} & 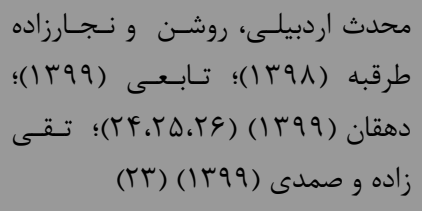 & دانشجويان خطر افتادن سـلامـت روان اسـاتـيـد، & \multirow{4}{*}{ اخلاقى } \\
\hline & 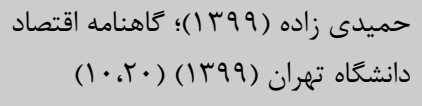 & كاهش جذ & \\
\hline & 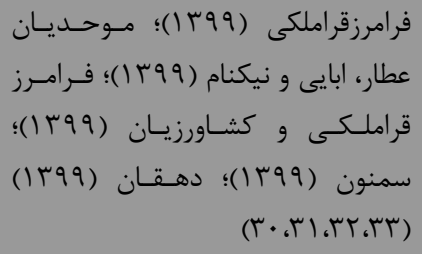 & جالش ديندارى & \\
\hline & تقى زاده (9 (1))(צ) & ترس از سرقت علمى، يِيَيرى قضـايسى و & \\
\hline $\begin{array}{l}\text { Ngumbi (2020); THE (2020) } \\
(|\vee .| \wedge)\end{array}$ & 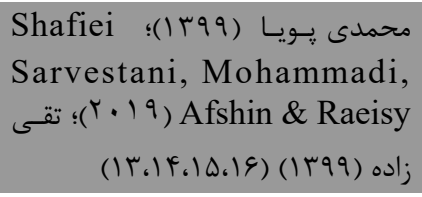 & دانشخاهها (به حـاشـيـه & \multirow{5}{*}{ 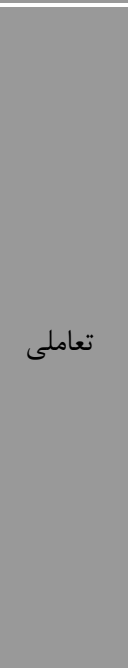 } \\
\hline \multirow[t]{2}{*}{$\begin{array}{l}\text { UNESCO (2020); Lau, Yang } \\
\text { \&Dasgupta (2020);(1 r)،(। })\end{array}$} & 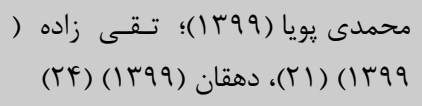 & 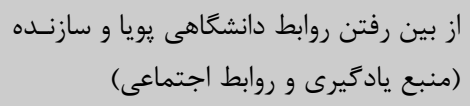 & \\
\hline & 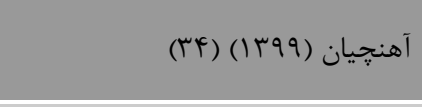 & 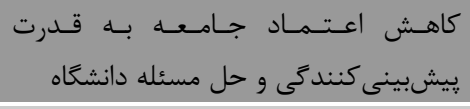 & \\
\hline $\begin{array}{l}\text { Lau, Yang \& Dasgupta (2020); } \\
\text { UNESCO }(2020)(11.1 \text { r) }\end{array}$ & & مشكل تطبيق ميان دانشجويان و اسـاتـيـد & \\
\hline $\begin{array}{l}\text { Lau, Yang \& Dasgupta } \\
(2020) ; \text { THE }(2020)\left(\mid r_{\cdot} \wedge \Lambda\right)\end{array}$ & & عدابقات جايخزين خوب براى سفرهاى ميدانسى، & \\
\hline $\begin{array}{l}\text { Ngumbi (2020);(IV) Lau, } \\
\text { Yang } \square \text { Dasgupta (2020); } \\
\text { Ngumbi (2020); Raoofi \& } \\
\text { etal. (2020)(I r.।V.rv) }\end{array}$ & 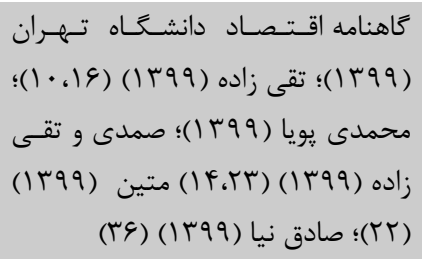 & كيفيت كمتر آموزش مجازى & 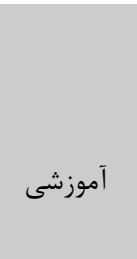 \\
\hline 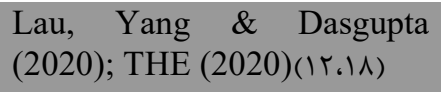 & 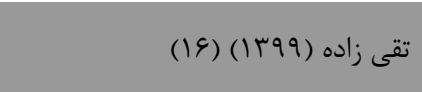 & تكاليف بيش از حد & \\
\hline
\end{tabular}




\begin{tabular}{|c|c|c|c|}
\hline جهان & 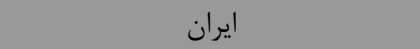 & فرصتها & 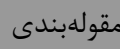 \\
\hline $\begin{array}{l}\text { Lau, Yang \& Dasgupta } \\
(2020) ; \text { Ngumbi }(2020) \\
\left(\mid Y_{\text {.lV }}\right) ; \text { THE }(2020)(1 \wedge)\end{array}$ & 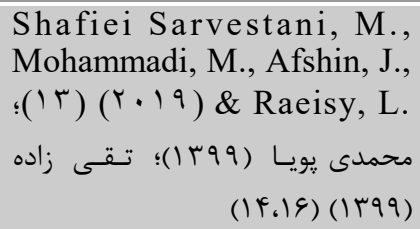 & كاهش تمايل بـهـ مشـاركت در آمـوزش & \\
\hline $\begin{array}{l}\text { Lau, Yang \& Dasgupta } \\
(2020) ; \text { THE }(2020)\left(\mid Y_{\text {، } \backslash \wedge)}\right.\end{array}$ & 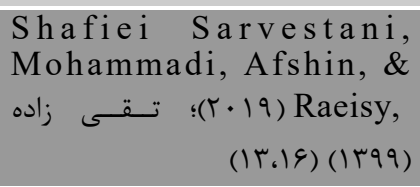 & كاهش تمركز و عدم جديت كلاسها & 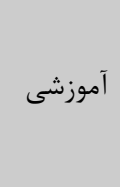 \\
\hline Sessoms $(2020)(r \wedge)$ & 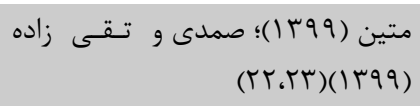 & كاهش دسترسى به اساتيد & \\
\hline Sessoms (2020); (r^) & تقى زاده (9१ץו) (19) & بىبرنامكى در آموزشها & \\
\hline
\end{tabular}

\section{جدول r: فرصتهاى آموزش عالى در دوران ياندمى كرونا ويروس 19. 19 در ايران و جهان}

\begin{tabular}{|c|c|c|c|}
\hline 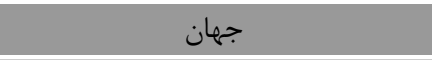 & 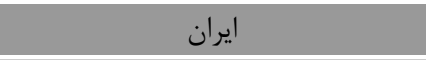 & فرصتها & مقولهبندى \\
\hline $\begin{array}{l}\text { Lau, Yang \& Dasgupta } \\
(2020) ; \text { THE }(2020)\left(\mid r_{\text {. }} \wedge\right)\end{array}$ & 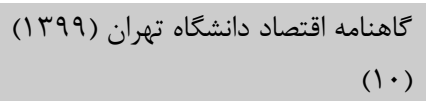 & كاهش شهريه در آموزش مجازى & \multirow{6}{*}{ اجرايى } \\
\hline & 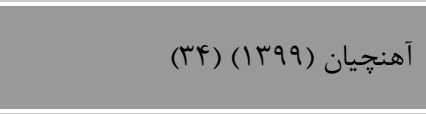 & رويكرد جديد به اقتصاد آموزش عالى: تغيير & \\
\hline $\begin{array}{l}\text { UNESCO (2020); Ngumbi } \\
(2020) \text {; Vershitskaya \& etal } \\
(2019)(|\backslash,| \vee \cdot Y l)\end{array}$ & 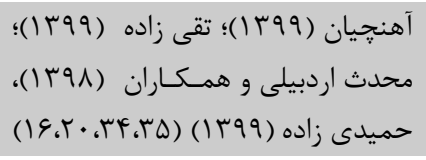 & 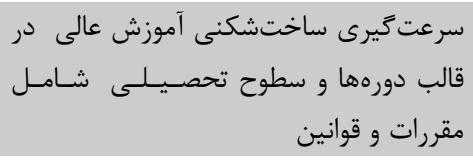 & \\
\hline $\begin{array}{l}\text { UNESCO (2020); Ngumbi } \\
(2020)(11.1 \mathrm{~V})\end{array}$ & 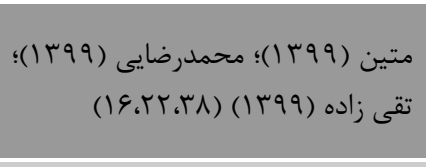 & 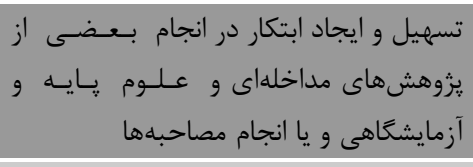 & \\
\hline Ngumbi (2020)(IV) & متين (Y)(IT) (Y) & 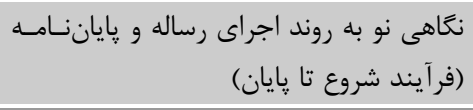 & \\
\hline UNESCO (2020)(11) & 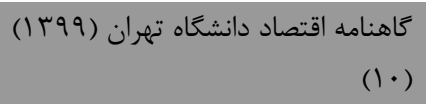 & يشتيبانى فناورى آموزش & \\
\hline $\begin{array}{l}\text { Mohd Al-Tawfiq,J\& Memish } \\
(2020)\left({ }^{*}\right)\end{array}$ & 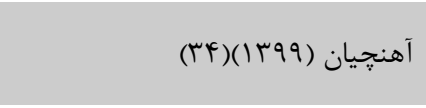 & 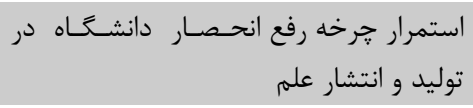 & مالى \\
\hline 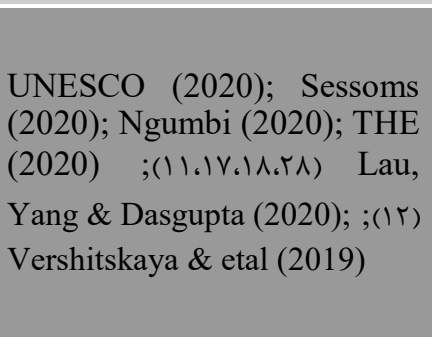 & 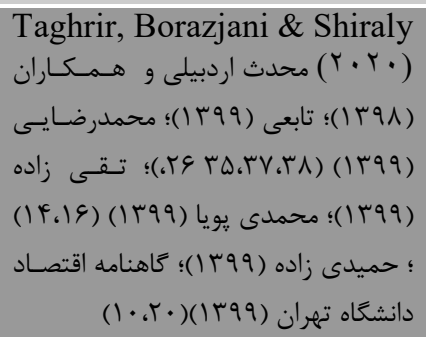 & و شرايط بحاد آمادى نسبت به بيمارى -هاى مشابـهـ & \multirow{3}{*}{ 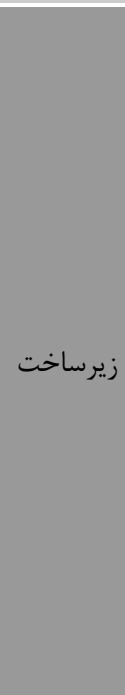 } \\
\hline $\begin{array}{l}\text { Lau, Yang \& Dasgupta } \\
(2020)(1 \mathrm{r}) \\
\text {;UNESCO (2020); Ngumbi } \\
\text { (2020); Mohammadimehr } \\
(2010)\left(11.1 \mathrm{Q}_{\text {.IV })}\right.\end{array}$ & 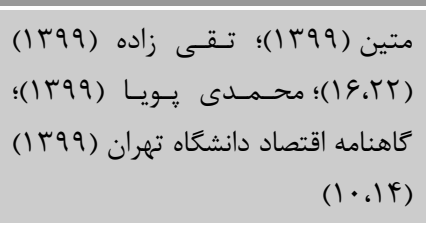 & 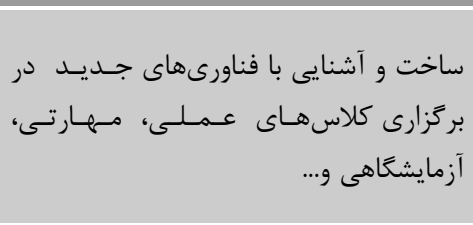 & \\
\hline 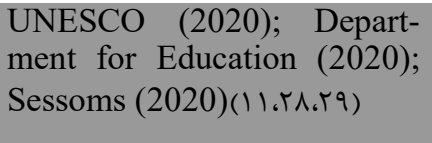 & 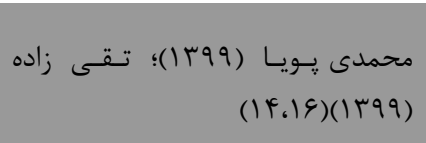 & 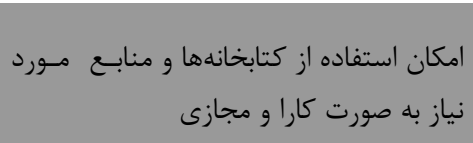 & \\
\hline
\end{tabular}




\begin{tabular}{|c|c|c|c|}
\hline جهان & ايران & فرصتها & مقولهبندى \\
\hline $\begin{array}{l}\text { Sessoms (2020); Ngumbi } \\
(2020) ; \text { UNESCO }(2020)) \\
(11.1 \vee .1 \wedge\end{array}$ & 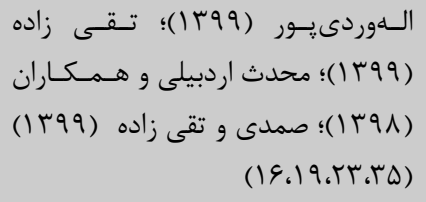 & 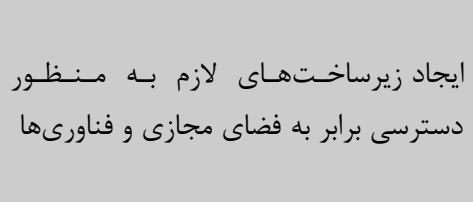 & زيرساخت \\
\hline \multirow[t]{3}{*}{$\begin{array}{l}\text { UNESCO (2020); Ngumbi } \\
(2020)(11.1 \mathrm{~V})\end{array}$} & 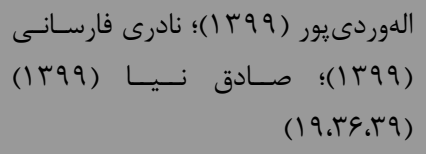 & 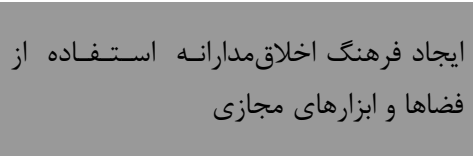 & \multirow[b]{3}{*}{ 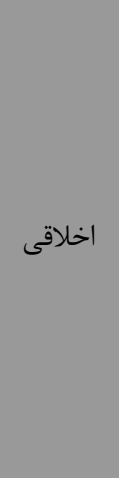 } \\
\hline & 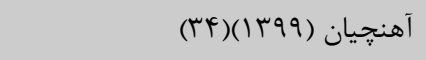 & باور به كاركردهاى انسانى آموزش و يثوهش & \\
\hline & 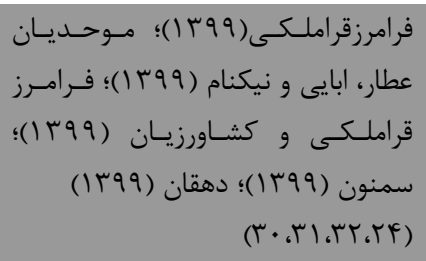 & 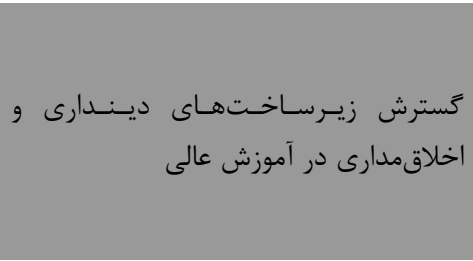 & \\
\hline \multirow[t]{3}{*}{$\begin{array}{l}\text { Ngumbi (2020); THE (2020) } \\
(|\vee \cdot| \wedge)\end{array}$} & 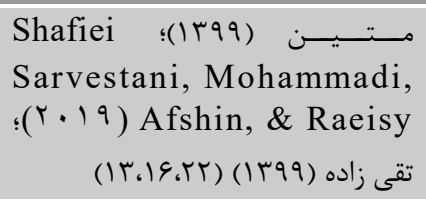 & 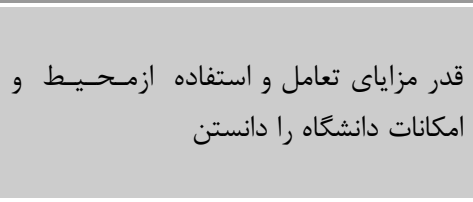 & \multirow{3}{*}{ 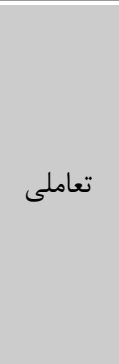 } \\
\hline & آهنجيان (IYq9) (IF) & 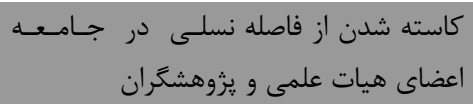 & \\
\hline & آهنجيان (1) (1) & كَترش پنداره دانشخاه در جامعه & \\
\hline $\begin{array}{l}\text { UNESCO (2020); Lau, Yang } \\
\text { \& Dasgupta (2020); ( } 1 \text { ، } 1 \text { r) }\end{array}$ & \multirow[b]{2}{*}{ تقى زاده ( (1) (1) (1) } & آموزش مجازى دستى مناسب به راهنماهـا بـــراى & \multirow{7}{*}{ آموزشى } \\
\hline $\begin{array}{l}\text { Lau, Yang \& Dasgupta } \\
\text { (2020); Ngumbi (2020) } \\
\text { (Ir.IV) }\end{array}$ & & 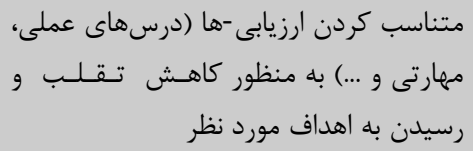 & \\
\hline $\begin{array}{l}\text { Lau, Yang \& Dasgupta } \\
(2020) \text {; THE (2020) } \\
(1 \wedge)\end{array}$ & & كروهوزش آز طريق رسانه و فيلم و .. به صورت & \\
\hline \multirow[t]{2}{*}{$\begin{array}{l}\text { Lau, Yang \& Dasgupta } \\
\text { (2020); Ngumbi (2020)( (Ir.IV) }\end{array}$} & & ادغام آموزش مجازى در آموزش حضورى & \\
\hline & آهنجيان (IFq৭)(IF) & رواج حلقههاى كوجٍى يادگيرى آموزشى & \\
\hline Ngumbi (2020)(IV) & 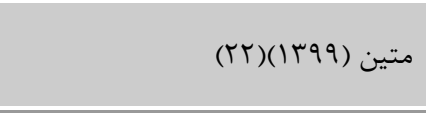 & 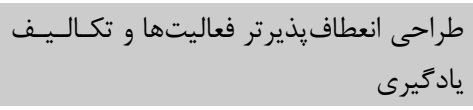 & \\
\hline Vershitskaya \& etal (2019) & متين (Y) (IT)(Y) & دقت بيشتر در تهيه محتواى مناسب & \\
\hline
\end{tabular}

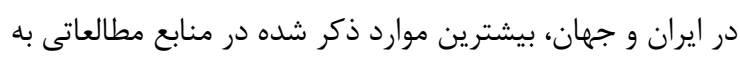

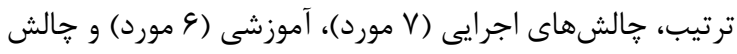

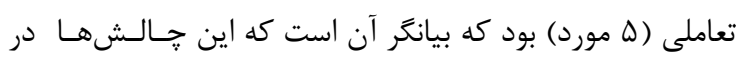

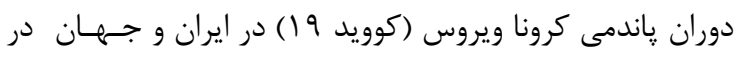

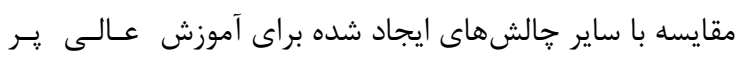

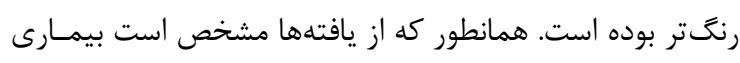

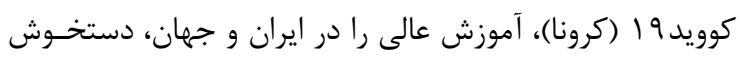

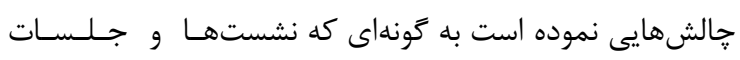

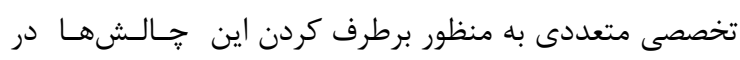

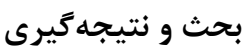

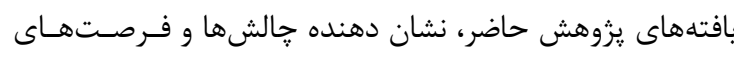

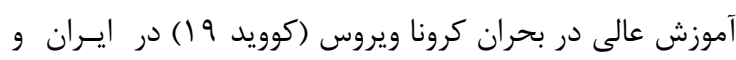

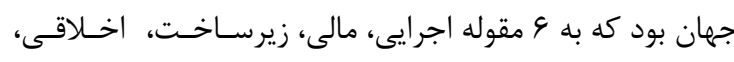

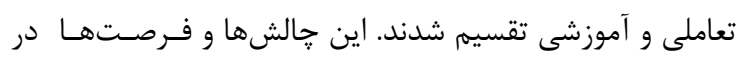

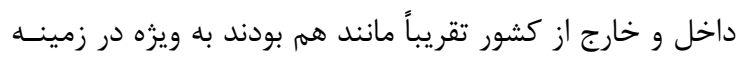

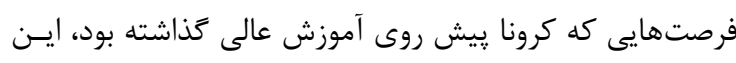

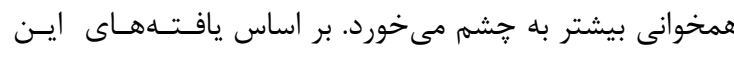

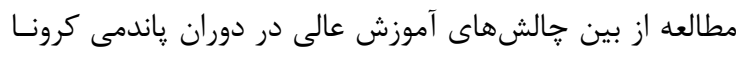




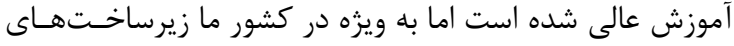

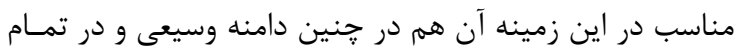

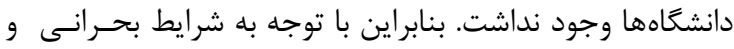

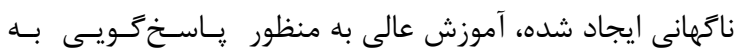

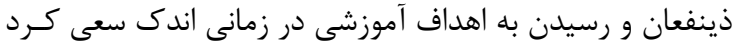

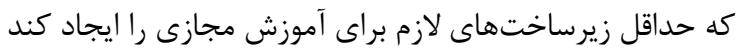

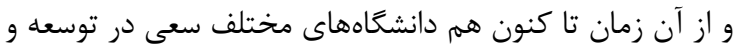
ارتقاى زيرساختهاى مربوطه نمودهاند.

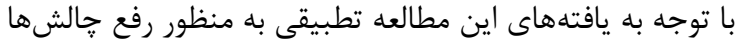

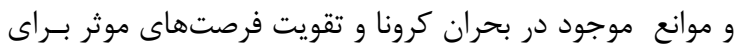

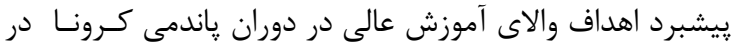
ايران راهكارهاى زير توصيه مى كردد:

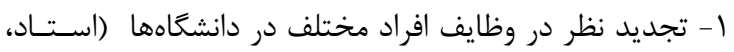
دانشجو، ....).

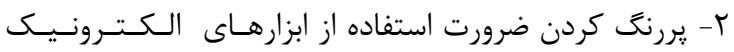
شخصى در آموزش (موبايل، تبلت و ...).

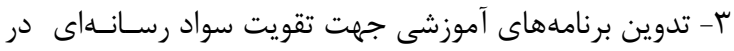

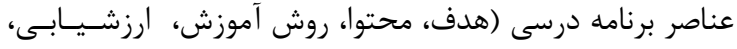
سايتهاى مكمل، فوق برنامه و و...).

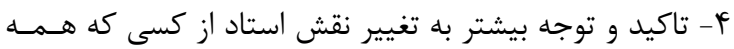

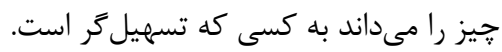

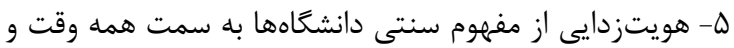

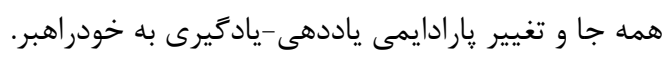

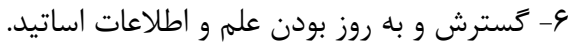

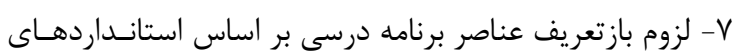
آموزش مجازى و تركيبى (هدف، محتوا، استاد، دانشجو، محيط، فضا، زمان، ارزشيابى و.

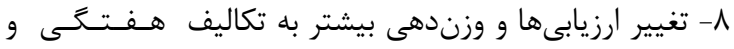

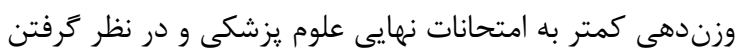

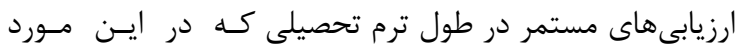

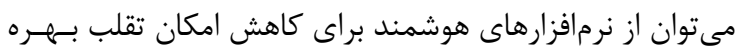

9- بهره كيرى از شبيهسازها براى دروس آزمايشحاهى، كار كاهى

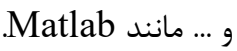

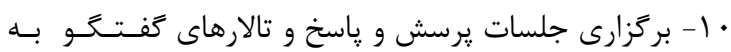
صورت مجازى براى دانشجويان.

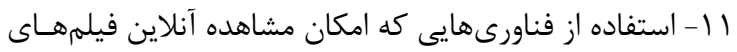

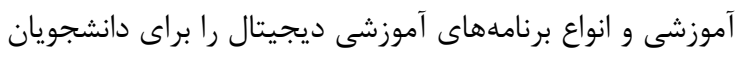

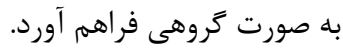

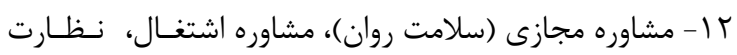
پايان نامه و ساير خدمات يشتيبانى دانشجويان.

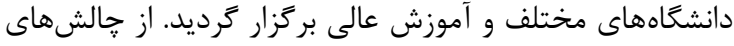

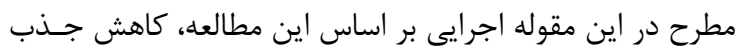

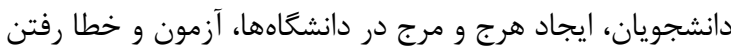

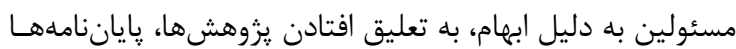

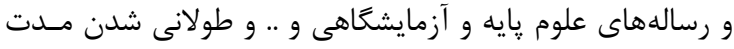

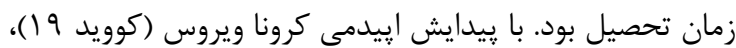

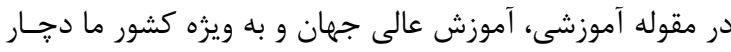

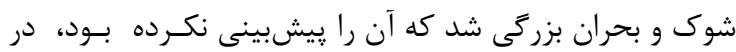

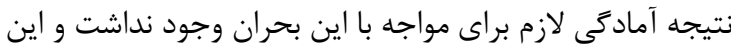

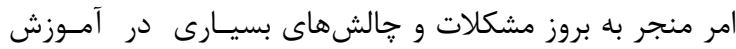

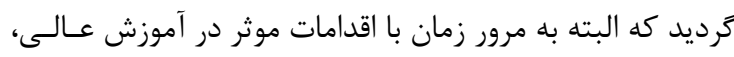

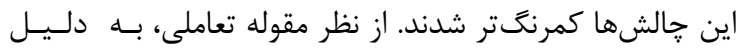

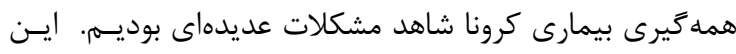

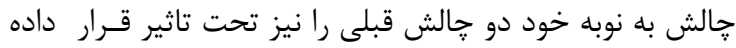

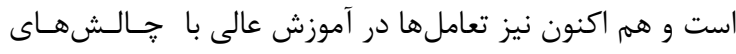
بسيارى مواجه است.

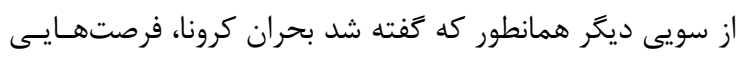

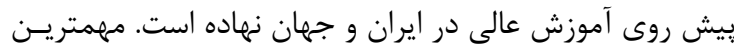

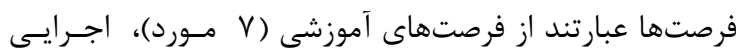

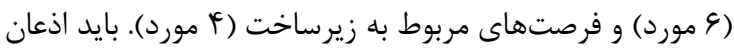

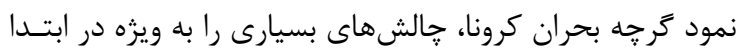

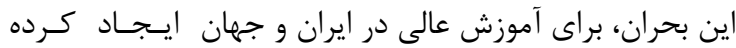

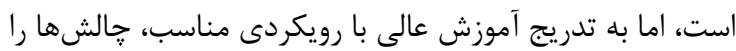

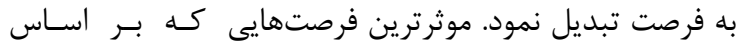

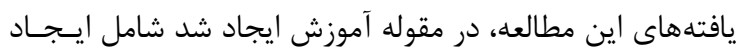

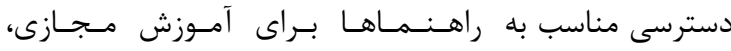

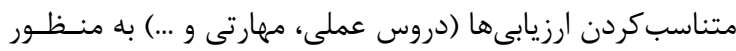

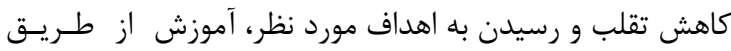

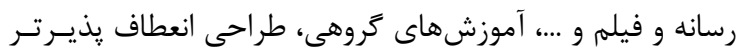

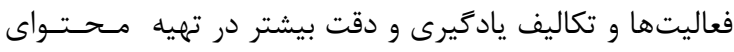

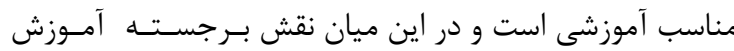

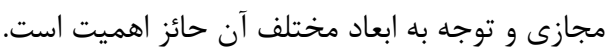

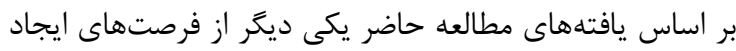

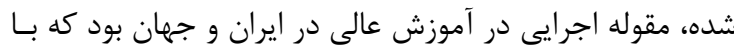

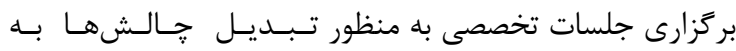

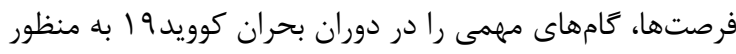

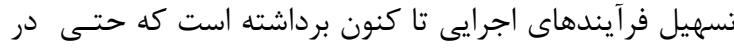

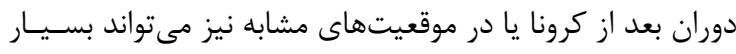

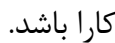

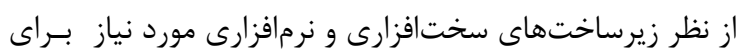

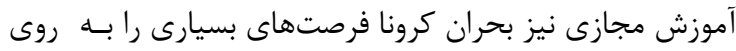

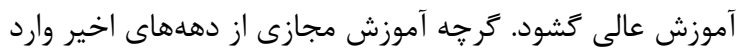


بf براى آموزش مجازى (مانند قلم نورى و ...).

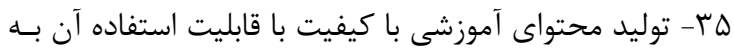
دفعات براى دانشجويان. وبـ- ايجاد و توسعه شبكههايى با كيفيت و مناسب براى ترائ تدريس

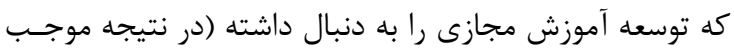
صرفههاى اقتصادى، همافزايى، عدالت آموزشى و همكارى ميان آنان

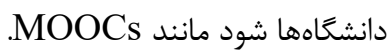

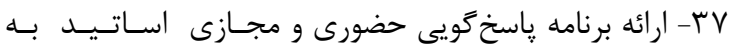
دانشجويان در دانشخاهها.

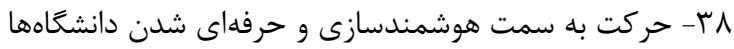
با رعايت الزامات اثربخشى آن در لايههاى مختلف.

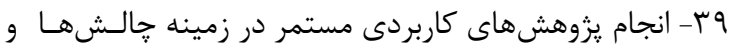

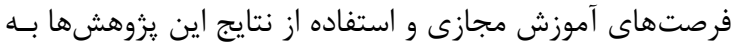

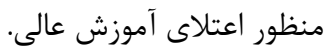

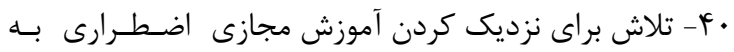
آموزش مجازى استاندارد در دانشكاهها.

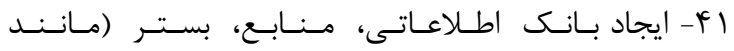

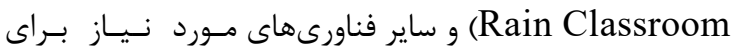
آموزش مجازى دانشخاه.

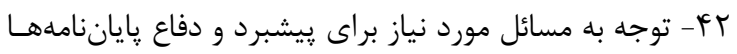

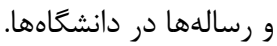

rا - آماده سازى اساتيد و دانشجويان در زمينه فناورى، فضـاى مجازى و يتانسيل هاى آن (كار كاهها، راهنماها و و..). أ أ شناسايى و بهرهيرى تجارب موفق ساير كشورها در زمينه

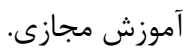
ها - توجه به اهميت و لزوم آموزش تركيبى.

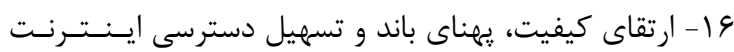

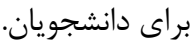
Vا ا - به روز و با كيفيت كردن مداوم فناورىهاى لازم به منظـور

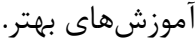
1 1 - تدوين تروتكلهاي، قيترانين، آيينامهها و ساير تمهيدات مورد نياز براى دانشكاهها. 9 ا - فراهممآوردن بسترى براى تعامل بين دانشجويان به اساتيـد

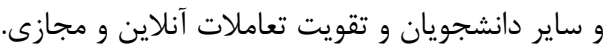

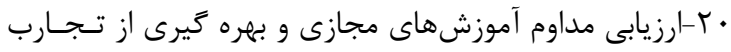

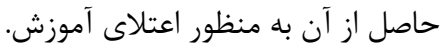
ا آ - دسترسى به كتابخانه آنلاين.

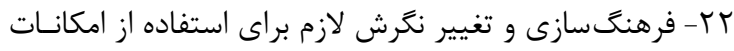

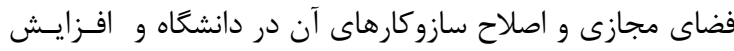

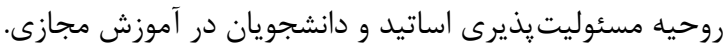

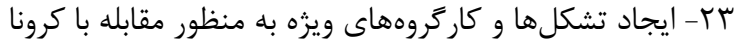
و آثار آن بر آموزش. آنجاد تثكل هF

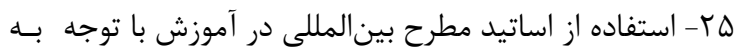
مجازى شدن كلاسها و حذف محدوديتهاى زمانى و مكانى.

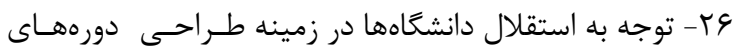

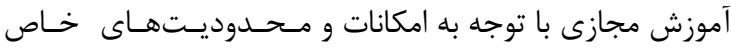

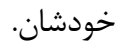

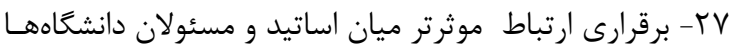

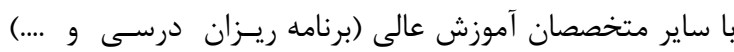
جهت طراحى دورههاى با كيفيت تر آموزش مجازى إنى

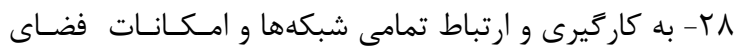
مجازى و ظرفيتسازى به منظور بومى كردن بهترين فنساورى هـا

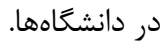

و ج- انواع حمايتها به ويزه مالى و اجتماعى از دانشجويان.

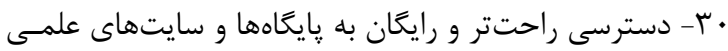
و منابع آنها براى دانشجويان و استاتيد. آب- دسترسى آسان دانشجويان در هر زمانى به فايل هاى صوتى تدريس هايى كه استاد در سامانه قرار داده است داست

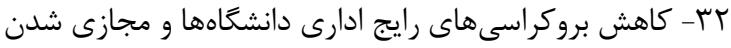

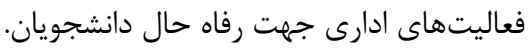
r بـ- طراحى و خلق الكوهاى جديد و كاربردى تدريس متناسب

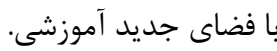




\section{References}

1- Alsoufi A, Alsuyihili A, MsherghiA, Elhadi A, Atiyah H, Ashini A, et al. Impact of the COVID-19 pandemic on medical education: Medical students' knowledge, attitudes, and practices regarding electronic learning. PLoS ONE. 2020;15(11): 1-20.

2- Aristovnik A, Keržič D, Ravšelj D, Tomaževič N, Umek L. Impacts of the COVID -19 pandemic on life of higher education students: A global perspective. Sustainability. 2020; Jan;12(20):8438.

3- Eskandarian Gh. Evaluating the consequences of coronavirus on lifestyle (with emphasis on cultural consumption pattern). Social Impact Assessment Quarterly. 2020; 4 (2):6585 (persian)

4- Ghafouri-Fard M. The boom in e-learning in Iran: The potential that flourished with the Corona virus. Iranian Journal of Medical Education. 2020;20 (4): 33-34.(persian)

5- Rezaei A. Student learning evaluation during the Corona: Challenges and Strategies. Educational Psychology. 2020 Apr 20;16(55):179 -214. (persian)

6- Al-Balas M, Al-Balas HI, Jaber HM, Obeidat $\mathrm{K}, \mathrm{Al}-\mathrm{Balas} \mathrm{H}$, Aborajooh EA, Al-Taher R, Al-Balas B. Distance learning in clinical medical education amid COVID-19 pandemic in Jordan: current situation, challenges, and perspectives. BMC medical education. 2020 Dec;20(1):1-7.

7- Sonal Chandratre MD. Medical Students and COVID-19: Challenges and Supportive Strategies. Journal of Medical Education and Curricular Development.2020 Sep; 7(12):1-2..

8- Gaur U, Majumder MA, Sa B, Sarkar S, Williams A, Singh K. Challenges and opportunities of preclinical medical education: COVID -19 crisis and beyond. SN Comprehensive Clinical Medicine. 2020 Sep 22:1-6.

9- Alikhani A. Methods of improvement and transformation of higher education and research in Iran with an analysis of some studies. Iranian Higher Education Association Quarterly. 2010; 3 (1): 1-31 (persian).

10- University of Tehran, Journal of Economics Retrieved from the Faculty of Economics, University of Tehran. Retrieved 2020-08-06 from: https://economics.ut.ac.ir

11- UNESCO U. COVID-19 educational disruption and response. UNESCO. 2020 Mar 4.

12- Lau J, Yang B, Dasgupta R. Will the coronavirus make online education go viral. Times Higher Education. 2020 Mar;12. from: https:// www.timeshighereducation.com/features/willcoronavirus-make-online-education-go-viral 13-. Shafiei Sarvestani M, Mohammadi M, Afshin J, Raeisy L. Students' experiences of e- learning challenges; a phenomenological study. Interdisciplinary Journal of Virtual Learning in Medical Sciences. 2019 Sep 1;10(3):1-10. (persian).

14- Mohammadi Pouya S. Education and Corona; Challenges. Assess actions, post-corona developments and crisis policies. Tehran: Hekmat Political Research and Strategic Studies Research Institute., 2020 June 8.

15- Mohammadimehr M. eLearning as an educational response to COVID-19 epidemic in Iran: The role of the learners support system. Future of Medical Education Journal. 2020 Sep 1;10(3):64-65.

16- Taghizadeh S. Challenges of e-learning from students' point of view and providing solutions. National Conference on E-Learning Challenges in Higher Education, Bu Ali Sina University of Hamadan and Deputy Minister of Education of the Ministry of Science. 2020 Oct 30.

17- Ngumbi E. Coronavirus closings: Are colleges helping their foreign, homeless and poor students. USA Today. 2020 Mar 17:11-4.

18- THE B. The impact of coronavirus on higher education. Retrieved 2020-03-23 from: https:/www.timeshighereducation.com/hub/ keystone-academic-solutions/p/impactcoronavirus-higher-education

19- Allah Ordipour H. The Global Health Communication Challenge: Infodem in the Coronavirus Pandemic Education and Community Health 2020; 7 (2): 65-67.(persian)

20- Hamidizadeh A. Efficiency of governments in corona management. A series of scientific-cultural sessions on the Corona Challenge and the Faithful Life of the University of Tehran, 2020 May 6.

21- Vershitskaya ER, Mikhaylova AV, Gilmanshina SI, Dorozhkin EM, Epaneshnikov VV. Present-day management of universities in Russia: Prospects and challenges of e-learning. Education and Information Technologies. 2020 Jan;25(1):611-21.

22- Matin A. The impact of the corona virus on world higher education. Tehran: Research Institute for Cultural and Social Studies, Ministry of Science, Research and Technology., 2020 April 27.

23- Samadi P , Taghizadeh, S. Higher education in the shadow of Corona. Virtual Conference on Human-Social Dimensions of Corona in Iran, Encyclopedia Research Institute of the Institute of Humanities and Cultural Studies, 2020 June 26.

24- Dehghan M. Religious faith; Corona and family. Sixth pre-conference of the International Conference on Ethics, Theology and Inclusive Disasters on the topic of religious faith, 
the death of thought and Corona disease, Beheshti University. 2020 May 17.

25- Ardabili M, Roshan F, Najarzadeh Torqabeh $\mathrm{E}$. The role of psychologists in natural crises (Case study: Prevalence of coronary heart disease in Iran). New Research in the Humanities. 2020; 4 (58): 167-172. (persian)

26- Tabii Z. Relaxation and immune system. A series of scientific-cultural sessions on the Corona Challenge and the Faithful Life, $2020 \mathrm{Ju}-$ ly: Tehran, iran. University of Tehran.2020.

27- Raoofi A, Takian A, Sari AA, Olyaeemanesh A, Haghighi H, Aarabi M. COVID-19 pandemic and comparative health policy learning in Iran. Archives of Iranian medicine. 2020 Apr 5; 23(4) :220-34.

28- SESSOMS B. Homeless students during the coronavirus pandemic:'We have to make sure they're not forgotten'. Statesville. com. Retrieved. 2020:03-23.

29- Department for Education Further and higher education: coronavirus (COVID-19). Retrive 2020-06-24, from:https://www.gov.uk/ government/collections/further-and-highereducation-coronavirus-covid-19

30- Gharamaleki A. Corona and the image of God. A series of scientific-cultural sessions on the Corona Challenge and Faithful Living, University of Tehran, 2020 May 6.

31- Gharamaleki A, Keshavarzian A. Coronary heart disease and moral dilemmas. The third pre-session of the International Conference on Ethics, Theology and Inclusive Disasters of Beheshti University. 2020 Sep. 25.

32- Movahedian A, Abai A, Niknam K. Widespread disasters from the perspective of religions (Islam, Judaism and Zoroastrianism). The fourth pre-session of the International Conference on Ethics, Theology and Inclusive Disasters, Beheshti University, 2020 May 4.

33- Semnoon M. Corona disease and death consciousness. Sixth pre-conference of the International Conference on Ethics, Theology and Inclusive Disasters on the topic of religious faith, the death of thought and Corona disease, Shahid Beheshti University, 2020 May 17.

34- Ahanchian, M. Unveiling of post-corona higher education, national conference on corona and faithful life,Tehran, 2020 Oct 1.

35- Ardabili Abolfazl M, Javadian N , Azadmanesh $\mathrm{M}$,Makian A. Corona (definitions, interventions, consequences). Journal of Strategic Studies of Humanities and Islamic Sciences 2020; 2 (23): 145-149. (persian)

36- Sadeghnia, M. Corona and the Challenge of Religiosity. A series of scientific-cultural sessions on the Corona Challenge and Faithful Living, University of Tehran. 16 August 2020. 37- Taghrir M, Borazjani R., Shiraly R. COVID-19 and Iranian Medical Students; A Survey on Their Related-Knowledge, Preventive Behaviors and Risk Perception. Arch Iran Med. 2029; 23 (4): 249-254. (perian)

38- Mohammad Rezaei M. coronavirus; Medicine and Western sciences. A series of scientific-cultural sessions on the Corona Challenge and the Faithful Life of the University of Tehran, 2020 May 6.

39- Naderi Farsani S. Strategic Challenges of Culture and Coronavirus. Series of ScientificCultural Meetings on the Corona Challenge and Faithful Living, University of Tehran. 2020 August 16.

40- Mohd H, Al-Tawfiq J, Memish Z. Middle East Respiratory Syndrome Coronavirus (MERS-CoV) Origin and Animal Reservoir, Virology journal 2019; 13 (1): 87-99. 